Iranian Journal of Breast Diseases. 2022; 14(4):4-20.
Original Article

\section{Emotion Focused Therapy Enduringly Reduces Depression and Increases Self-Compassion in Women with Breast Cancer: A Semi-Experimental Study}

\author{
Salarirad $Z^{1}$, Leilabadi $\mathbf{L}^{2^{*}}$, Kraskian Mujembari $\mathrm{A}^{3}$, Salehi $\mathbf{M}^{2}$ \\ ${ }^{1}$ Ph.D. Student in Health Psychology, Department of Psychology, Faculty of \\ Psychology and Educational Science, Central Tehran Branch, Islamic Azad \\ University, Tehran, Iran \\ ${ }^{2}$ Department of Psychology, Faculty of Psychology and Educational Science, \\ Central Tehran Branch, Islamic Azad University, Tehran, Iran \\ ${ }^{3}$ Department of Psychology, Faculty of Psychology and Educational Science, \\ Karaj Branch, Islamic Azad University, Karaj, Iran
}

Receive: $17 / 8 / 2021$ Accepted: 1/12/2021

"Corresponding Author: lida.leilabadi@gmail.com

Ethics Approval: IR.IAU.CTB.REC.1400.016

\begin{abstract}
Introduction: Emotion-focused therapy (EFT) is designed to help patients identify and process their emotions. The aim of this study was to evaluate the effect of emotion-focused therapy on improving depression and self-compassion in women with breast cancer.

Method: This was a quasi-experimental study with a pretest-posttest design with a control group and a 3-month follow-up. The sample consisted of 30 women with breast cancer in Tehran who had a depression score of $>17$ at screening and were selected via purposive sampling and randomly placed in experimental and control groups of 15. The experimental group underwent EFTover twelve 50-minute individual sessions according to the Greenberg emotion-focused therapy protocol. Research data were collected using the Beck Depression Inventory and the Self-compassion Scale before, after, and 3 months after the end of treatment. Data analysis was performed using repeatedmeasures two-way ANOVA.
\end{abstract}

Results: The experimental group scored significantly higher in selfcompassion and lower in depression in the posttest compared with the pretest. In the follow-up assessment, depression scores were as low as the posttest levels, but self-compassion scores decreased relative to the posttest; however, they remained significantly above the pre-test levels. In the control group, both depression and self-compassion scores were stable over time.

Conclusion: EFT can be used as an appropriate intervention to reduce depression and increase self-compassion significantly and enduringly in women with breast cancer.

Keywords: Emotion-Focused Therapy, Depression, Self-Compassion, Breast Cancer 


\section{Introduction}

Anxiety and depression are among the most common forms of psychological distress in most cancer patients (1). Breast cancer can challenge patients' core beliefs about invulnerability, safety, and self-worth and can lead to depression, uncertainty, body image concerns, and somatic symptom issues (2). Self-compassion is another variable that is related to mental health and subsequently to physical health. It contributes to enhanced emotional resilience and reduced depression and anxiety in patients (3). Research findings demonstrate that the sub-threshold rules in the Iranian culture can result in anger and sadness following patterns of suppressed emotional expression, increasing the experience of negative emotion for the individual and negatively affecting their overall mental health and psychological well-being (4). Therefore, researchers and psychologists emphasize the importance of therapies that can help regulate and express emotions. Emotion-focused therapy (EFT) has been developed and expanded as a treatment protocol for processing and regulating emotion and its application is considered in improving social health indicators. The present study aims to investigate the effect of EFT on depression and self-compassion in women with breast cancer.

\section{Methods}

The study was conducted with a semiexperimental pretest-posttest design and involved a control group and a 12-week follow-up. The population of the study consisted of women with breast cancer who had visited a general surgeon and oncologist at Rasoul Akram Hospital and Khatam-ulAnbia Cancer Clinic in Tehran during 20202021. Thirty people were selected using purposive sampling method and randomly assigned to two groups of 15 people (experimental and control group). All the participants completed the Beck Depression Inventory (BDI), 2nd edition, Selfcompassion Scale (SCS) (Neff, 2003) at three stages. The experimental group received 12 weekly sessions of individual emotion-focused therapy, with each session lasting for 50 minutes $(5,6)$. Data were analyzed using the two-factor analysis of variance with repeated measures of one factor and the Bonferroni post hoc test.

\section{Results}

The mean (SD) ages of the experimental group and the control group were 45.60 $(\mathrm{SD}=8.11) \quad$ and $43.40 \quad(\mathrm{SD}=6.94)$, respectively. An independent $t$ test showed that there was no significant difference between the groups in terms of age $(\mathrm{P}<0.05)$. Participants were also homogeneous in terms of education level, family history of cancer, number of breast surgeries, disease stage, and neoadjuvant chemotherapy ( $\mathrm{P}$ 's $<0.05$ ). Mixed analysis of variance was also carried out (Table 1).

Post hoc analyses with the Bonferroni correction showed that EFT significantly reduced depression symptoms and increased self-compassion.

\section{Discussion}

Expression, processing, and regulation of emotions can help reduce the cognitiveemotional symptoms of depression in breast cancer patients, reduce negative attitudes through self-compassion and protective anger, and improve the associated somatic symptoms. Staying in contact with emotional experience, conscious exploration of it, reflection, and understanding the meaning of the emotional experience are alternative mechanisms for reducing the subjects' depression. Transforming maladaptive schemas and rewriting them through creating new patterns of emotional processing helps clients not to reengage in painful primary maladaptive emotions and to avoid such experiences, something that seems to explain the consistency of treatment outcomes. On the other hand, acceptance of pain, instead of avoiding it, can help to explain the effectiveness of emotional therapy in increasing compassion. 
Table 1- Descriptive Indicators and Results of Mixed aAnalysis of Variance of Depression and Self-Compassion

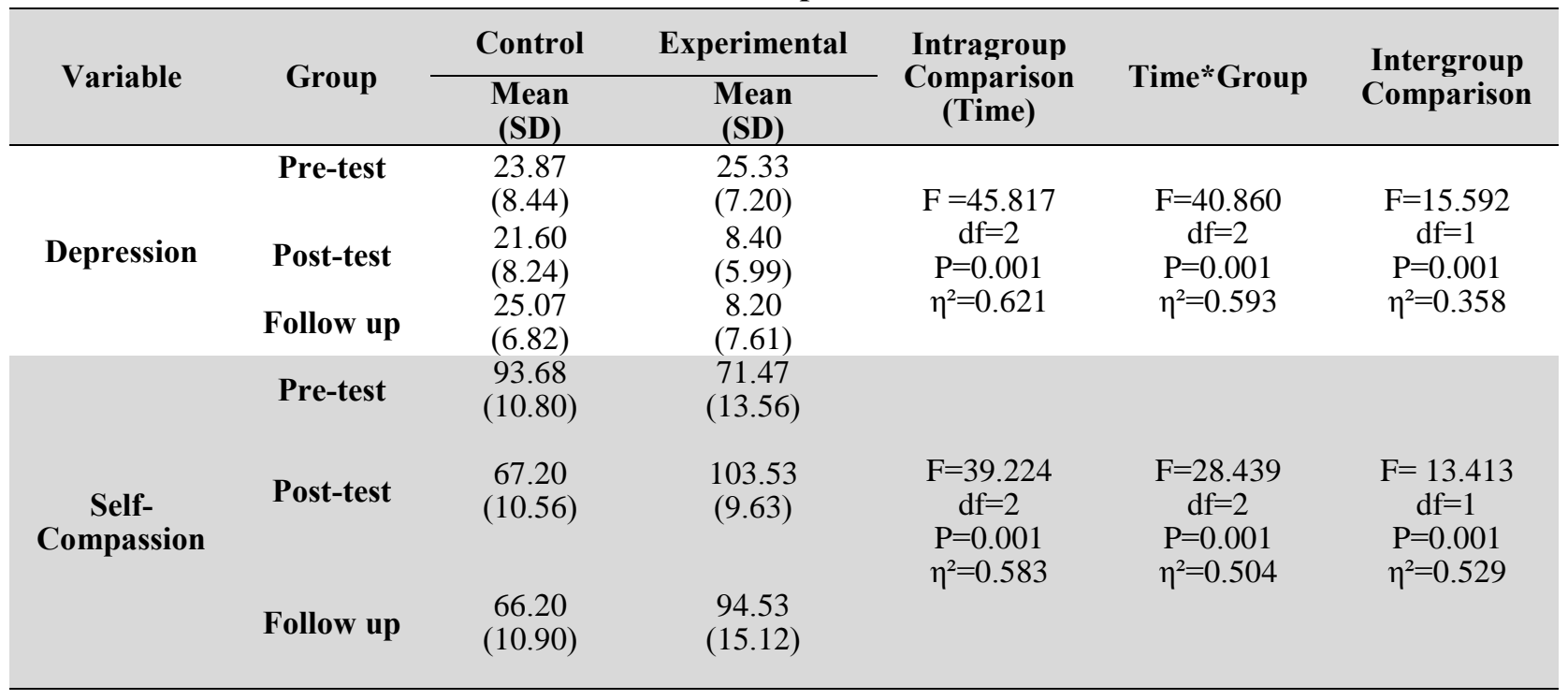

The limited number of treatment sessions for this group of participants seems to have prevented the consolidation of the effects of the treatment on self-compassion from taking place.

\section{References}

1. Nakamura ZM, Deal AM, Nyrop KA, Chen YT, Quillen LJ, Brenizer T, Muss HB. Serial assessment of depression and anxiety by patients and providers in women receiving chemotherapy for early breast cancer. The Oncologist. 2021; 26(2): 147-56.

1. 2 Kyei KA, Oswald JW, Njoku AU, Kyei JB, Vanderpuye V, Tschida P. Anxiety and Depression among Breast Cancer Patients Undergoing Treatment in Ghana. African Journal of Biomedical Research. 2020; 23(2): 227-32.

2. Van der Donk LJ, Fleer J, Tovote A, Ranchor AV, Smink A, Mul VEM et al. The role of mindfulness and self-compassion in depressive symptoms and affect: A Comparison between Cancer Patients and

\section{Conclusion}

The results of the present study showed that EFT can significantly reduce depression and increase self-compassion in patients with breast cancer. Therefore, the results can help researchers, therapists, and health professionals in designing appropriate interventions for these patients.

Healthy Controls. Mindfulness. 2020; 11(4): 883-94.

3. Hashemian S, Shams G, Ashayeri H, Modarres Gharavi M. Investigating the impact of emotional display rules on the positive/negative affect. Journal of Fundamentals of Mental Health, 2016;18(6): 338-42.

4. Greenberg LS. Emotion-focused therapy: Coaching clients to work through feelings. Washington DC: American Psychological Association. 2015.

5. 6. Elliott R, Watson JC, Goldman RN, \& Greenberg LS. Learning emotion-focused therapy: The process-experiential approach to change. Washington DC: American Psychological Association. 2004. 


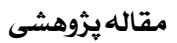

كاهش باثبات افسردىى و افزايش شفقتخود در زنان مبتلا به سرطان يستان با درمان متمركز بر هيجان: يك مطالعه نيمه آزمايشى

زهرا سالارى راد'، ليدا ليل آبادى “"، آديس كراسكيان موجمبارى"، مهديه صالحى'

' دانشجوى دكترى روانشناسى سلامت، كروه روانشناسى سلامت، دانشكده روانشناسى و علوم تربيتى،

دانشَاه آزاد اسلامى، واحد تهران مركزى، تهر انه، ايران

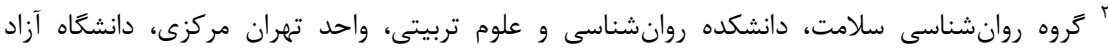

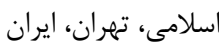

"ج كروه روانشناسى سلامت، دانشكده روانشناسى، واحد كرج، دانشكاه آزاد اسلامى، كرج، ايران
فصلنامه بيمارى هاى يستان ايران

$1 \varepsilon \cdots ! \mid \varepsilon(\varepsilon): \varepsilon-r$.

\section{جكيله}

مقدمه: درمان متمركز بر هيجان براى كمكى به بيماران در شناسايى، استفاده و يردازش

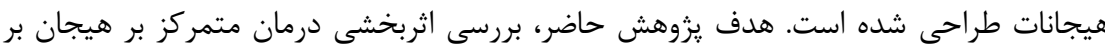

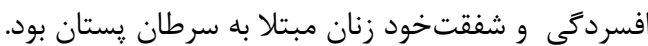

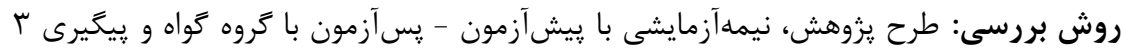

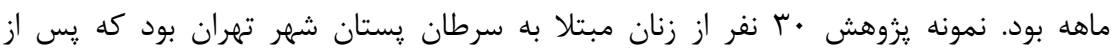

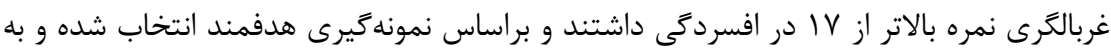

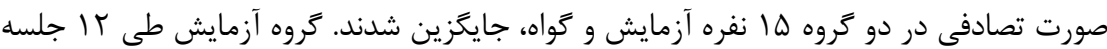

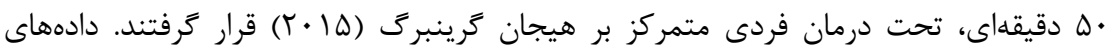

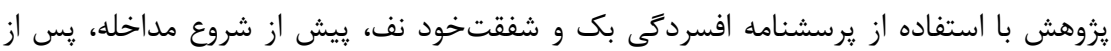

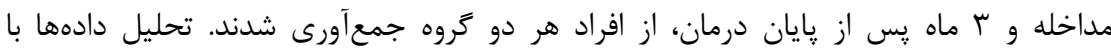

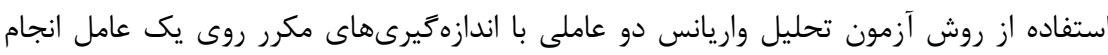

يافتهها: كروه آزمايش نمرهى بالاترى در شفقت خود و نمره كمترى در افسردىى در مرحله

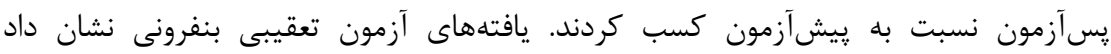

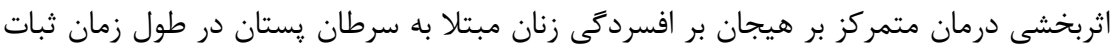

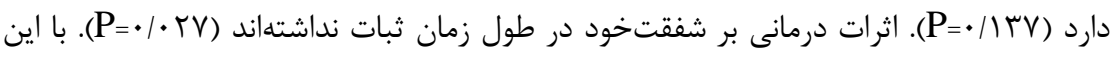

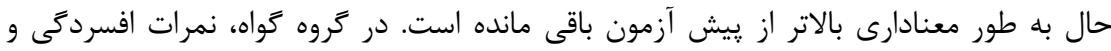

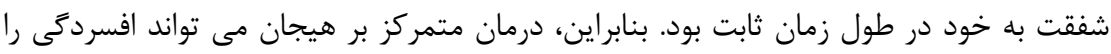

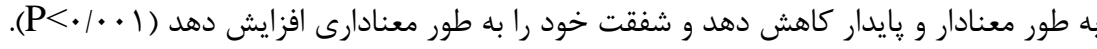

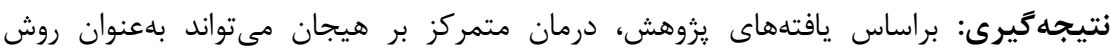

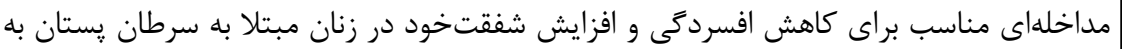
كار رود. - ماخ |وازٔهاى كليدى: درمان متمركز بر هيجان، افسردىى، شفتخود، سرطان يستان

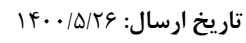

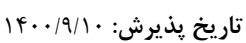

"نويسنده مسئول: lida.leilabadi@gmail.com 
بيماران مبتلا به سرطان كه شفقتخود بالاترى دارند،

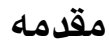
״يامدهاى منفى و علائم روانشناختى كمترى در :رخه

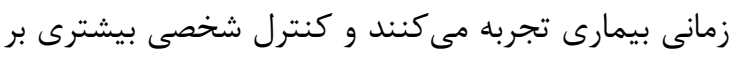

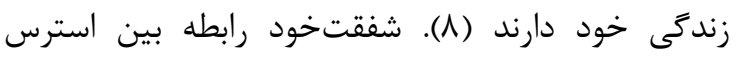

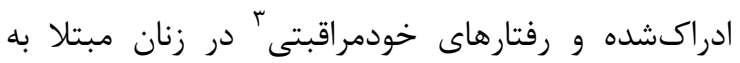
سرطان پستان را تعديل كرده (9) و در رابطه بين تصوير بدنى زنان مبتلا به سرطان و يريشانى نقش ميانجى دارد؛ اختلال در تصوير بدن و شفقتخود كمتر با افزايش

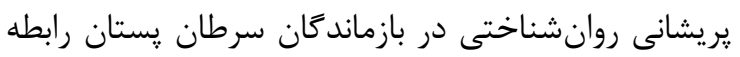

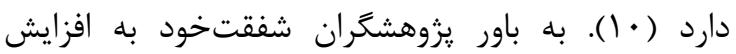

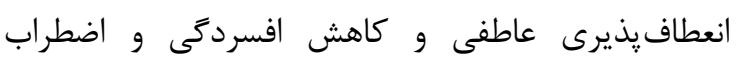
بيماران مبتلا كمك مى كند (1) يكى از درمانهايى كه مورد توجه درمانكران قرار كرفته،

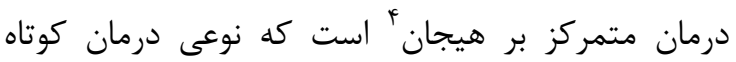
مدت و مبتنى بر شواهد به شمار مى آيد و از سنت

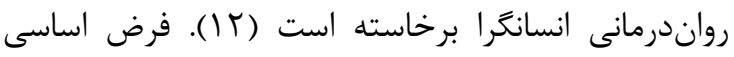

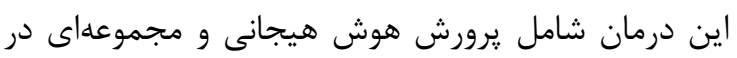

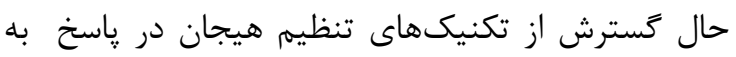

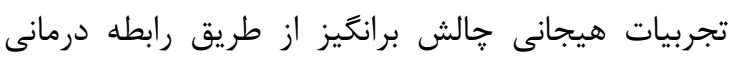
است (ץ ا). به باور يزوهشكران متمركز بر هيجان، هيجان

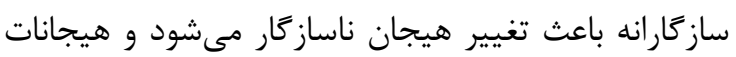
سازكارانهاى كه در طول درمان ابراز مىشوند بهترين ييشبينى كننده خروجى درمان هستند (f) (l). نتايج مطالعات مشابه بيانكر آن هستند كه درمان متمركز بر هيجان در كاهش افسردىى مؤثر است (ل||- آI). هيسا

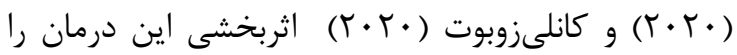
در كاهش افسردىى زنان مبتلا به سرطان يستان تاييد

مطالعات نشان مىدهد كه انتقاد از خود مىتواند با بال)

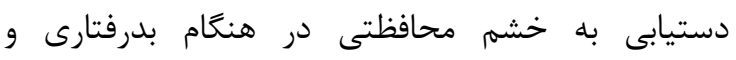

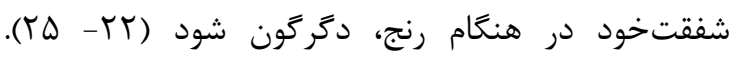
يزوهشها نشان دادهاند كه اصول درمان متمركز بر هيجان 
بيمارستان رسول اكرم و كلينيك سرطان خاتمالانبياى

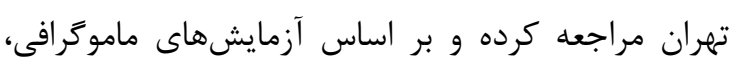
نمونهبردارى و قضاوت بالينى انكولوزيست، مبتلا به مانه سرطان پِتان تشخيص گذارى شده بودند. از آنجايى كه

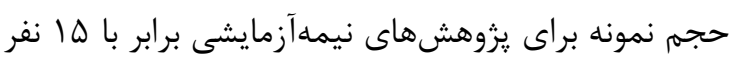

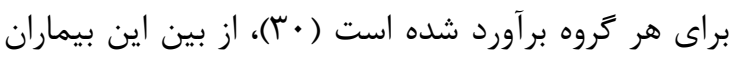

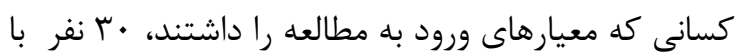
استفاده از روش نمونه گيرى هدفمند انتخاب و به روش تصادفى به دو گروه ها نفرى (آزمايش و گروه گواه) تخصيص داده شدند. شركت كنندكان در اين يزوهش در در

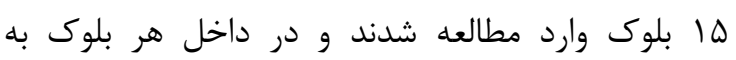
صورت تصادفى به يكى از گروه هاى مداخله و و عدم

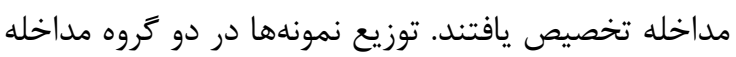

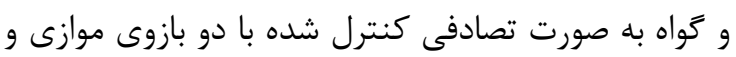
نسبت تخصيص 1:1 بود. معيارهاى ورود عبارت بود از: ابتلا به سرطان پستان (در مرحله يك، دو و سه بيمارى)، سن هץ تا فه سال، متاهل، عدم باردارى يا دوره

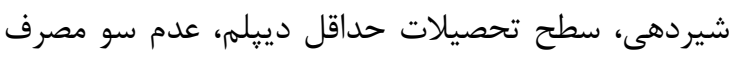

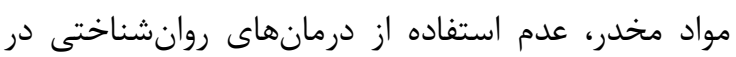
حداقل دو ماه قبل از اولين جلسه، عدم سابقه بسترى در بيمارستان روانيزشكى، عدم استفاده از داروهاى روانيزشكى در دو ماه قبل از اولين جلسه. همجنين رونين

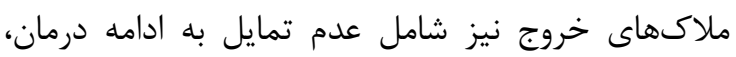

غيبت در جلسات درمانى بيش از دو جلسه متوالى بود. درمان متمركز بر هيجان يس از جلب همكارى يزشكان بيمارستان رسول اكرم و

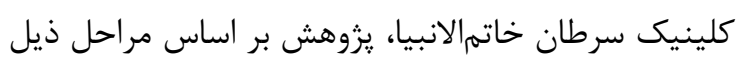

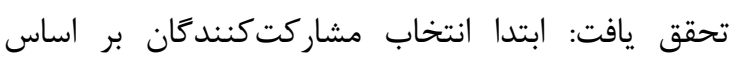
ملاكهاى ورودى تعريف شده و جيدمان آنها آنها در دو كروه

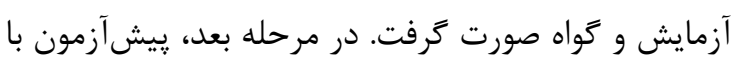

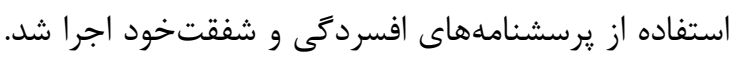

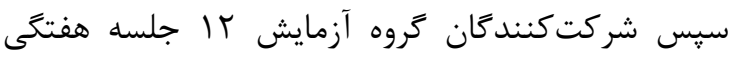
•ه دقيقهاى درمان متمركز بر هيجان را به صورت فردى ندى دريافت كردند. كروه كواه، هيج نوع مداخلهاى آزمايشى را
در كاهش انتقاد از خود، بهبود شفقتخود موثر است (عץ،

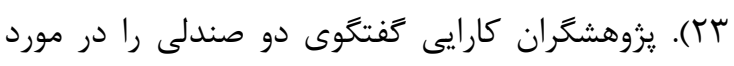

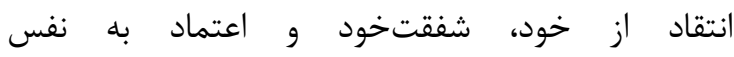
شركتكنندگان بسيار انتقادى بررسى كرده و همانطور

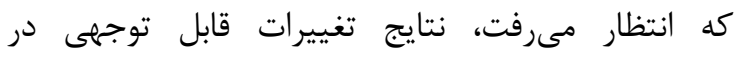
شفقتخود، اعتماد به نفس و انتقاد از خود نشان داد (ع)،

روانشناسان معتقدند فرايندهاى روانى متاثر از شرايط و

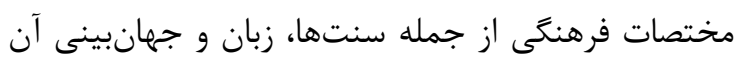
جامعه است. در همين راستا مىتوان به جمعَرايى

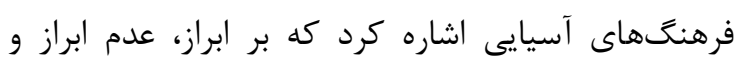

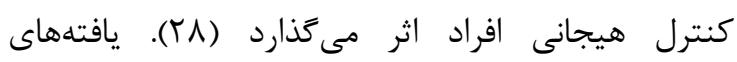

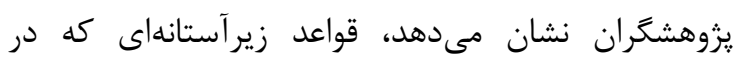
جريان فرهنكى كشور ايران وجود دارد باعث شده هيجانهاى خشم و غم از قواعد ابراز هيجان سركوبكرايانه تبعيت كنند كه تجربه عاطفه منفى را براى افراد به همراه دارند و سلامت روان و بهزيستى

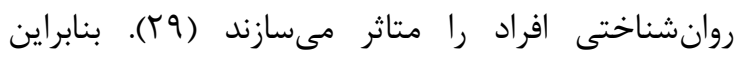

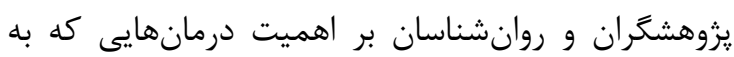
تنظيمى و ابراز سازگارانه هيجانات كمك كند تاكيد دارند. از اينرو امروزه كاربرد درمان متمركز بر هيجان، به عنوان

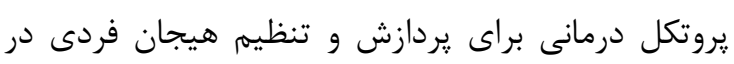
حال تكامل و گسترش است و دامنه كاربرد آن در بهببود شاخصهاى سلامت اجتماعى مورد توجه قرار ترفته است. با توجه به مطالب زفته شده يزوهش حاضر با هدف بررسى اثربخشى درمان متمركز بر هيجان بر افسردىى و شفقتخود زنان مبتلا به سرطان يستان انجام شد.

\section{مواد و روشها}

يزوهش حاضر از لحاظ هدف تحقيق كاربردى بود. يزوهش

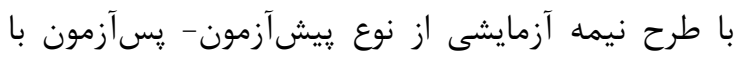

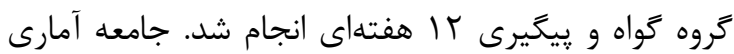
شامل زنان مبتلا به سرطان קֶتان بود كه در سال 91 91 9ه يزشك جراح عمومى و انكولوزيست در 
است (rr). كه در قالب آ نشانه و نكخرش گردآورى و در

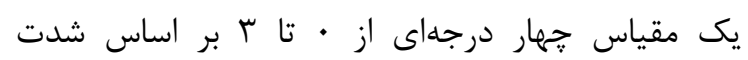

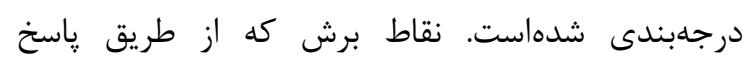

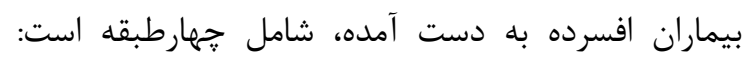

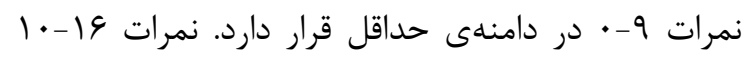

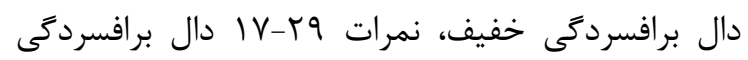
متوسط و نمرات ب به-•r دال برافسردكى شديد است.

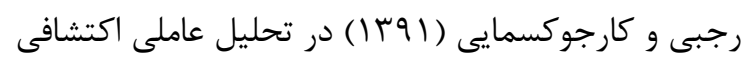

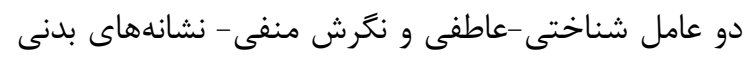

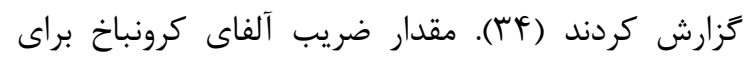

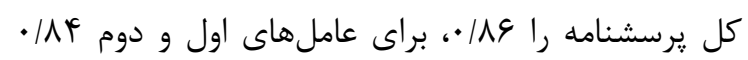

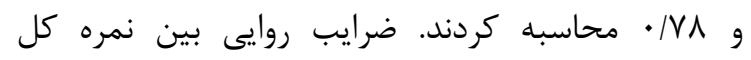

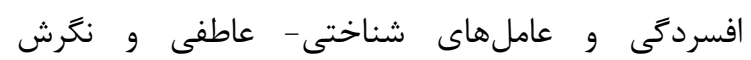

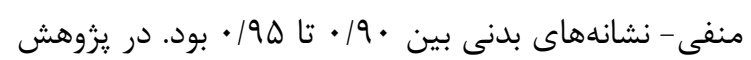
حاضر ضرايب آلفاى كرونباخ نمره كل افسردگى AVI • و و

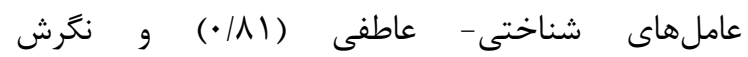
منفى - نشانههاى بدنى (9/^• ) به دست آمد.

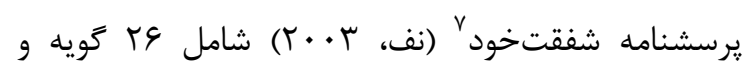
9 مولفه مهربانى با خود، قضاوت نسبت به خود، اشتراكات

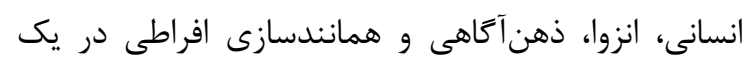
طيف ليكرت ه درجهاى از كاملاً مخالفم=ا تا كاملاًا

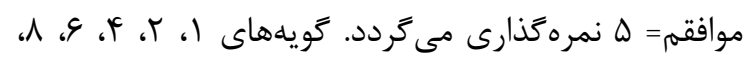

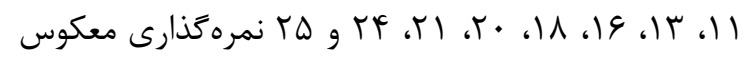

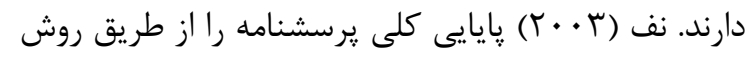

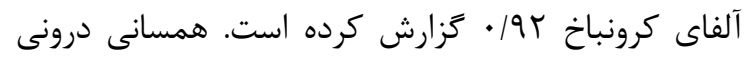

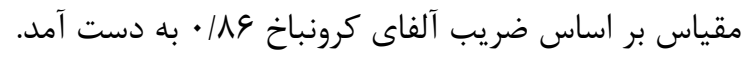

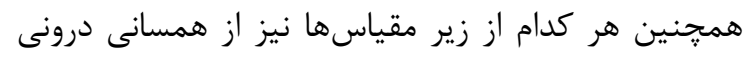

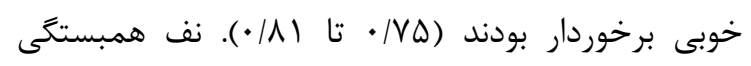

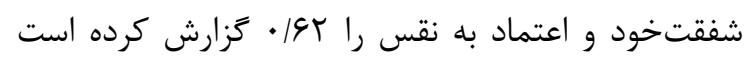

\footnotetext{
${ }^{7}$ Self-Compassion Scale
}

دريافت نكرده و فقط در شرايط ِيش آزمون و پِآزمون،

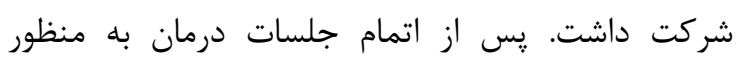
ارزيابى نتيجه جلسات، اعضاى هر دو گروه برسشنامه بهاى

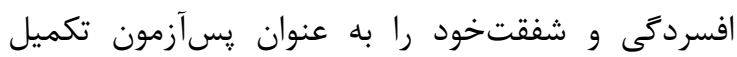
كردند. در نهايت براى پِيگيرى نتايج درمان و بررسى

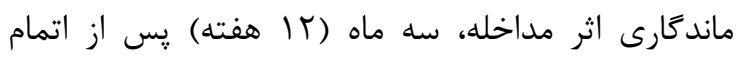
جلسات، اعضاى هر دو كروه مجددا يرسشنامهها را تكميل كردند. جهت حفظ ملاحظات اخلاقى يس از طى دوره

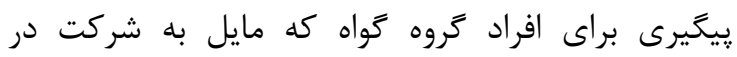
مداخله بودند، درمان متمركز بر هيجان اجرا شد. در برد جدول 1 خلاصه جلسات درمان متمركز بر هيجان ارائه

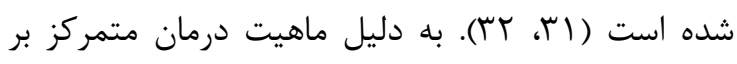

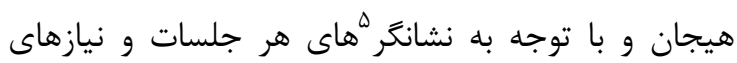
متفاوت مراجعان جلسات درمان لزوما متوالى نبود و كاهى محتواى جلسات تكرار مىشد. در اين يزوهش كد اخلاق

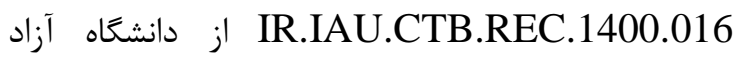
اسلامى واحد تهران مركز اخذ شد.

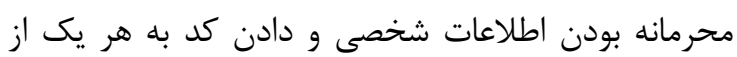

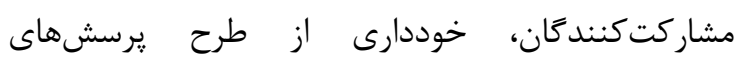
غيرضرورى و شخصى، عدم بايكانى نمودن اطلاعات غيرضرورى و خصوصى لحاظ شد. بهعلاوه تامين هزينه رفت و آمد بنابر تمايل، آزادى شركت لحكنيد جلسات درمانى در صورت عدم تمايل به ادامه درمان و

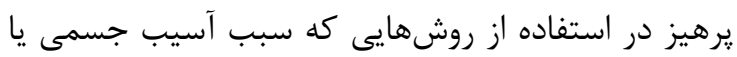

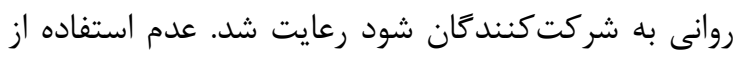
منابع مشكوك و فاقد اعتبار علمى و اجتماعى در طرح و له رعايت امانتدارى و صداقت در تجزيه و تحليل و ارائه

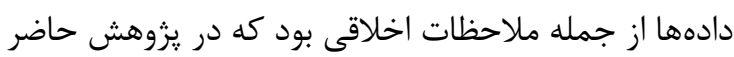
مد نظر قرار كرفت. ابزارهاى اين يزوهش عبارت بودند از؛ يرسشنامه افسردگى فرى

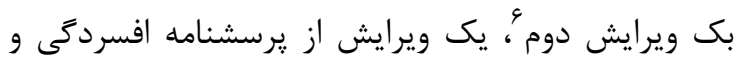
شاخص خودززارشى در جمعيتهاى بالينى و غيربالينى

\footnotetext{
${ }^{5}$ Marker

${ }^{6}$ Beck Depression Inventory-II
} 
جدول ا: محتواى جلسات درمان متمركز بر هيجان

شرح جلسات

آشنايى كلى با مراجع، معرفى درمانكر و اجراى بيشآزمون. ارزيابى هيجانى، تشكيل اتحاد درمانى، بررسى اوليه مشكلات، نكرانىها و انتظارات مراجع.

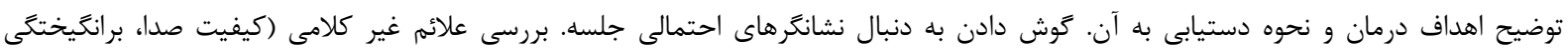

هيجانى و نحوه روايت).

مربيخرى هيجان. شناسايى، تجربه و درك معناى هيجانات مراجع، تشويق مراجع به ابراز هيجانات اساسى (مانند غم، خشم، شرم، ترس از وخامت و عود

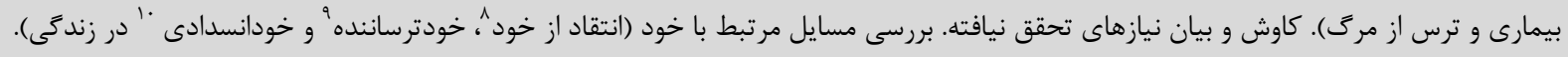

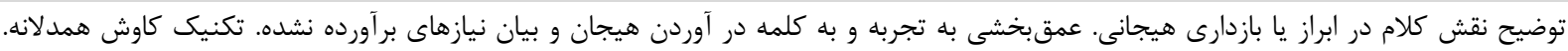

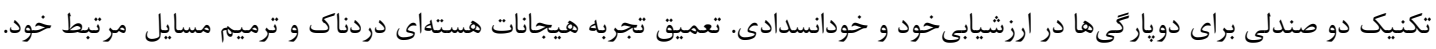
بررسى مسايل مرتبط با ديكران و اشخاص مههم و تاثير گذار در زندگى و اجراى تكنيك صندلى خالى. شناسايى و تمايز دادن هيجانات اوليه و ثانويه و

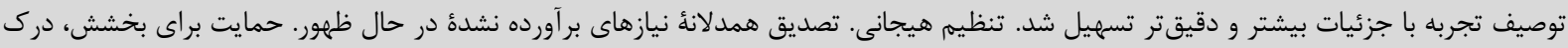
يا مسئول دانستن ديكرى.

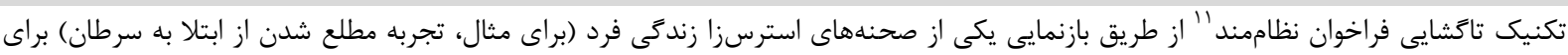

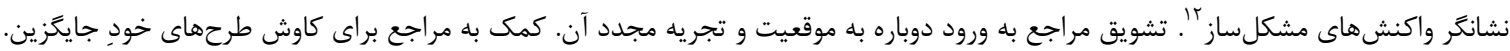

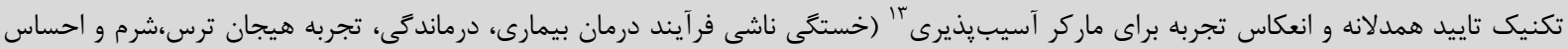

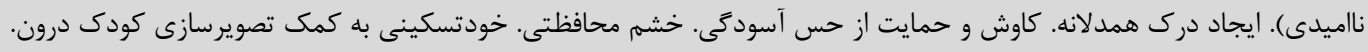

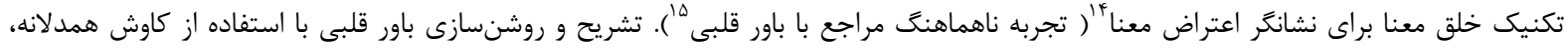
همدلى فراخوانى كننده، گمانهزنى همدلانه، استعاره، درك همدلانه. تسهيل كاوش مراجع از عواقب و اعمال احتمالى بر پائؤ باور قلبى تجديد نظر شده. تسهيل خودتسكينى، شفقت خود. يردازش مجدد تجربيات مشكل آفرين و هدايت فرآيند به شركت فعالانه مراجع در جلسه. ابراز و تنظيم هيجانات ثانويه. تقويت يردازش هيجانات ترس،

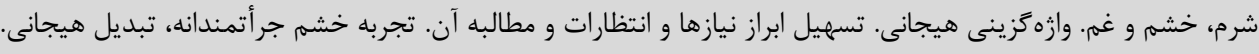

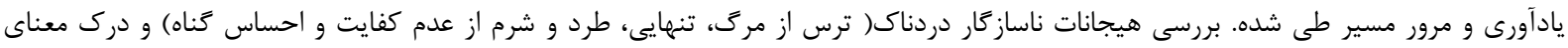

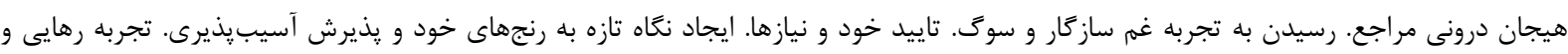

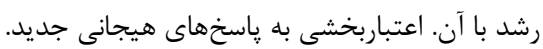

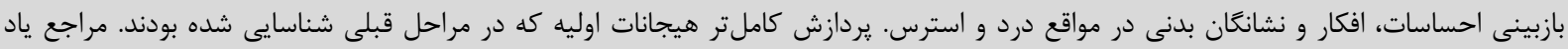

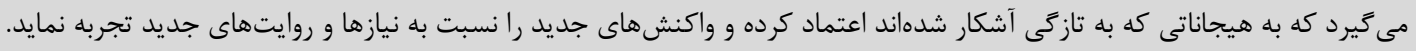
افزايش آكاهى و عامليت. توانمندسازى مراجع با اين تجربه كه هيجانات دربردارنده يُانسيل درونى انطباقى هستند و جنانجه فعال شوند، قادرند كمك

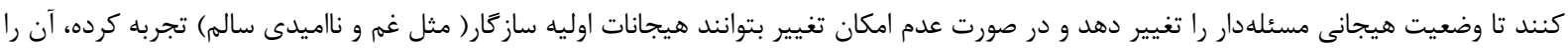
رها كنند و به مسيرهاى ديخر بيردازند. مقايسه تجربه هيجانى فعلى و كذشته. كَفتكو در مورد خودشفقتى، خودتسكينى و جراتورزى. جمعبندى تجربه جلسات و معناى جديد ساخته شده از

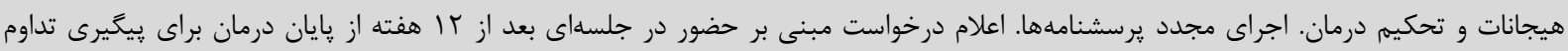
اثربخشى درمان.

\footnotetext{
${ }^{8}$ Self-critical

${ }^{9}$ Self-frightener

${ }^{10}$ Self- interruption

${ }^{11}$ Systematic evocative unfolding

${ }^{12}$ Problematic reactions

${ }^{13}$ Vulnerability

${ }^{14}$ Meaning protest

${ }^{15}$ Cherished beliefs
} 


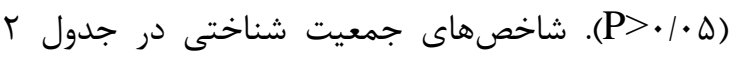

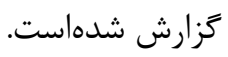

جدول ז: شاخصهاى جمعيت شناختى در كروههاى آزمايشى و كواه

\begin{tabular}{|c|c|c|}
\hline كروره تَواه & فراوانى تروه & شاخص \\
\hline & & تحصيلات \\
\hline r & r & دييلم \\
\hline 1 & r & كاردانى \\
\hline 9 & $\wedge$ & كارشناسى \\
\hline \multirow[t]{2}{*}{ r } & . & كارشناسى ارشد \\
\hline & & سابقه \\
\hline r & $\Delta$ & داراى سابقه \\
\hline \multirow[t]{2}{*}{ IT } & 1. & بدون سابقه \\
\hline & & تعداد جراحى يستان \\
\hline ir & ir & ا مرتبه \\
\hline \multirow[t]{2}{*}{ r } & r & r مرتبه \\
\hline & & نوع جراحى \\
\hline r & r & تخليه كامل بستان \\
\hline 11 & 1. & حفظ يستان \\
\hline \multirow[t]{2}{*}{ r } & 1 & يروتز حين جراحى \\
\hline & & درمان نئوادجوانت \\
\hline$\Delta$ & 9 & بلى \\
\hline 1. & 9 & خير \\
\hline
\end{tabular}

آزمون جندمتغيره لامبداى ويلكز در خصوص مراحل

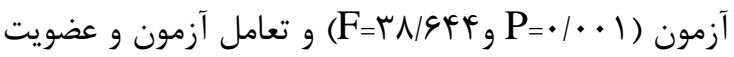
گروهى ( I • P

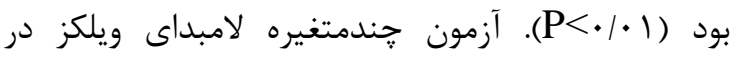
خصوص مراحل آزمون (1)

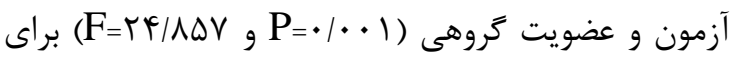
شفقتخود نيز معنادار بود. در ادامه تجزيه و تحليل

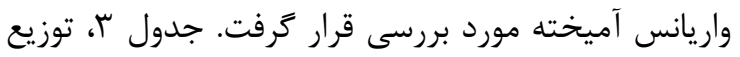
نمرههاى شركتكنندگان در متغير افسردى و نتايج حاصل از تحليل واريانس آميخته را نشان مىدهد.
خسروى، صادقى و يابنده (r9r) ضريب آلفا براى نمره

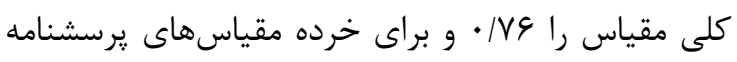

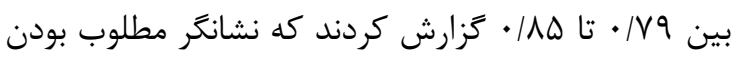
همبستخى درونى گويهها و پايايى ابزار است (هش). در يزوهش حاضر ضرايب آلفاى كرونباخ براى خرده مقياسهاى مهربانى با خود AF|•، قضاوت نسبت به خود

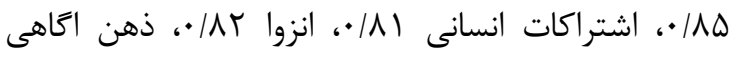
ع/1/•و همانندسازى افراطى •^//• به دست آمدهاست. ضريب آلفاى كرونباخ نمره كل نيز AV/ • محاسبه شد.

روش تحليل دادهها براى تجزيه و تحليل دادهاى يزوهش از روشهای روهاى آمار

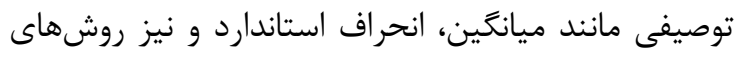

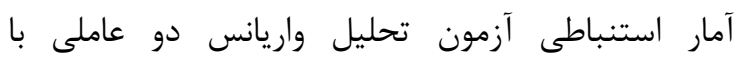

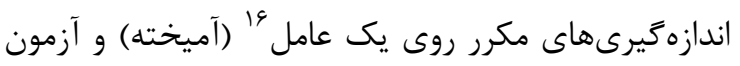

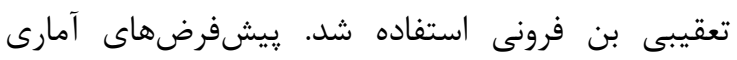

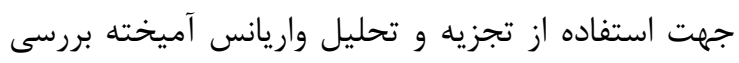

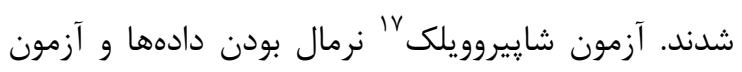

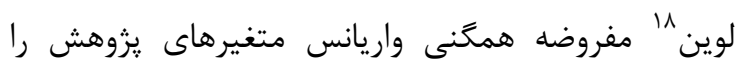

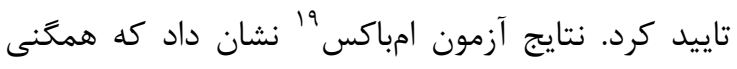
ماتريس واريانس - كوواريانس محقق شده است. فرض

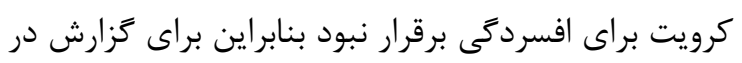

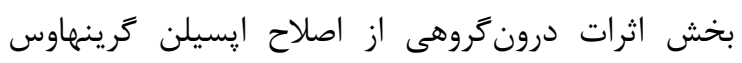

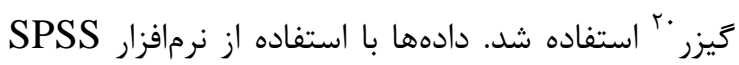
نسخه آ تجزيه و تحليل شدند.

كافتهها ميانگين و انحراف معيار سنى در گروههاى درمان متمركز

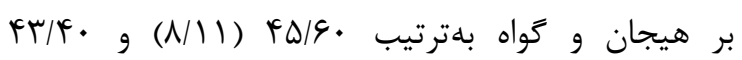

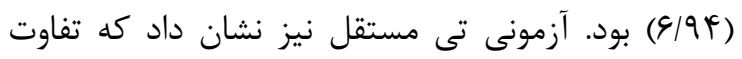

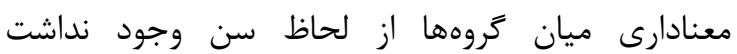

\footnotetext{
${ }^{16}$ Repeated Measures Two-way ANOVA (and mixed model)

${ }^{17}$ Shapiro. Wilk's Test

${ }^{18}$ Levene's Test

${ }^{19}$ Box's M Test

${ }^{20}$ Greenhouse-Geisser
} 
آزمودنىهاى كروه درمان متمركز بر هيجان افزايش يافته

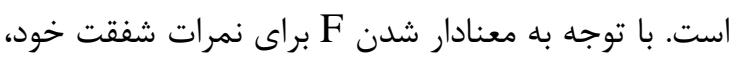
انجام مقايسههاى يس از تجربه ضرورى بنظر مىرسد، بنابراين از آزمون تعقيبى بنفرونى جهت برام برسى مجى مقايسهاى

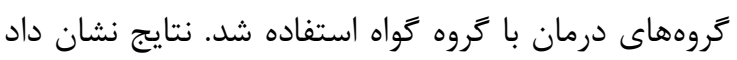
بين ميانكَين نمرات مهربانى با خود و نمره كل شفقت

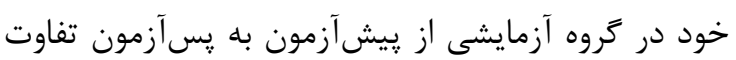

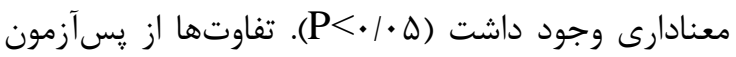
به يُخيرى نيز معنادار بود (ه (P</). به اين معنا كه اثرات درمانى بر مهربانى با خود و نمره كل شفقت خود در طول زمان ثبات نداشتهاند. بر اساس نتايج بهدست بآمده، بين ميانكين نمرات قضاوت نسبت به خود، اشتراكات انسانى، انزوا، ذهن آكاهى و همانندسازى افراطى در كروه

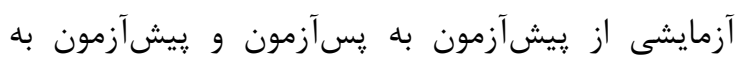

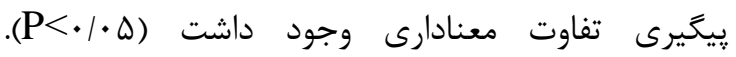

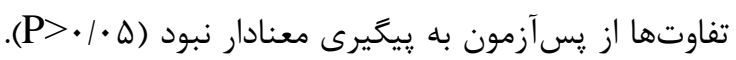
به اين معنا كه اثرات درمانى در طول زمان ثبات داشتهاند. بنابراين مىتوان نتيجه گرفت اثربخشى درمان متمركز بر بر مان هيجان بر ابعاد قضاوت نسبت به خود، اشتراكات انسانى،

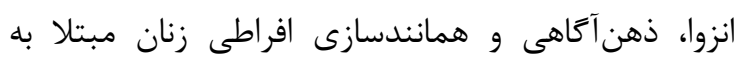
سرطان در طول زمان ثبات دارد. تغييرات مربوط به نمره كل شفقتخود در نمودار ب ترسيم شدهاست.

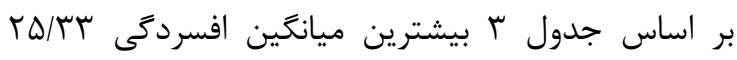
(V/T•) קيشآزمون براى كروه آزمايش بود. در مرحله يسآزمون

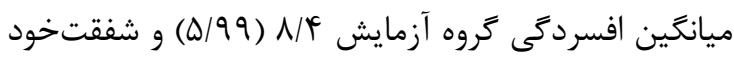

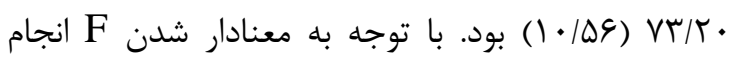
مقايسههاى يس از تجربه ضرورى بهنظر مىرسد، بنابراين

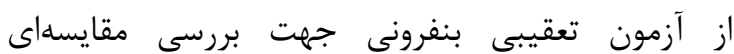
كروههاى درمان با كروه تواه استفاده شد.

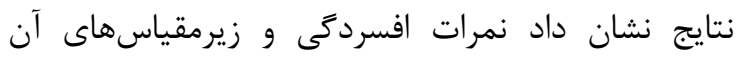
شامل نشانههاى شناختى - عاطفى و نكَرش منفى - نشانه

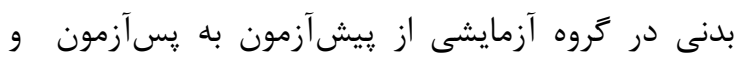

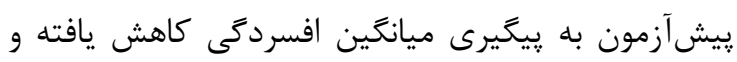

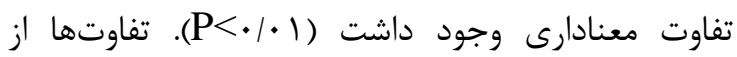

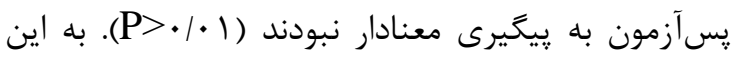
معنا كه اثرات درمانى در طول زمان ثبات داشتهاند. بنابراين مىتوان نتيجه گرفت اثربخشى درمان متمركز بر بر افسردىى زنان مبتلا به سرطان در طول زمان ثبات دارد. تغييرات مربوط به نمره كل افسردگى در نمودار 1 ترسيم شدهاست. جدول fا، توزيع نمرههاى شركت كنندكان در متغير شفقت خود و نتايج حاصل از تحليل واريانس آميخته را نشان مىدهد. نتايج جدول ع ع نشان مى دهد در ابعاد شفقت خود و همجنين نمره كل شفقت

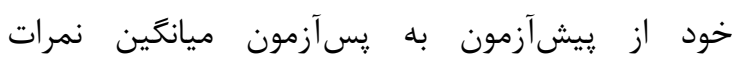

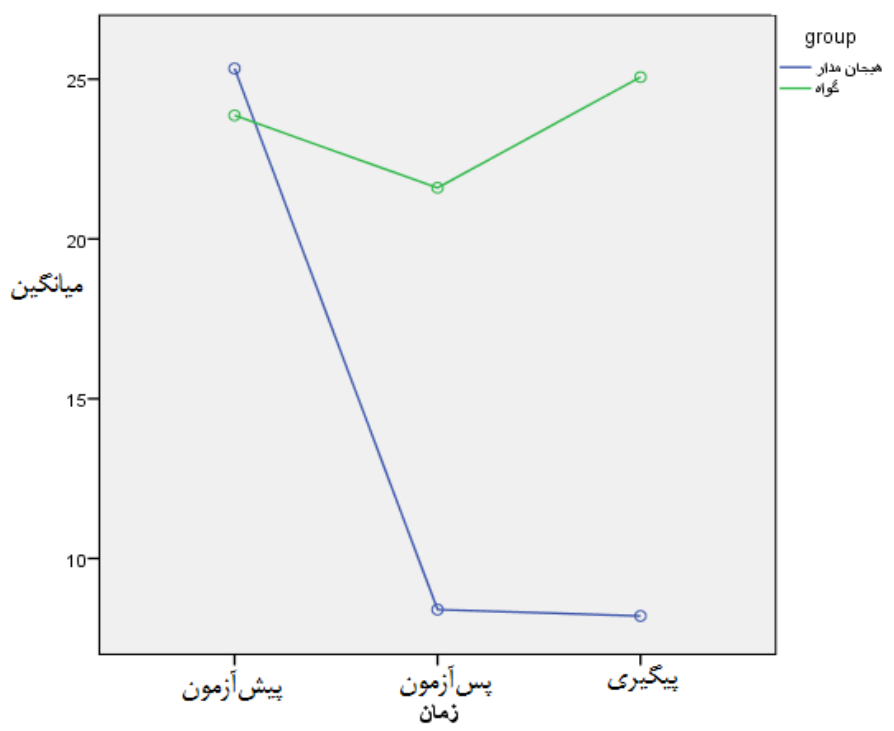


جدول r: شاخص هاى توصيفى و نتايج حاصل از تحليل واريانس آميخته افسردكى

\begin{tabular}{|c|c|c|c|c|c|c|}
\hline مقايسه بين & تعامل آزمون با & تروهى (آزمون) & 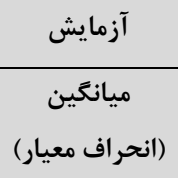 & $\begin{array}{c}\text { (انحر اف ميانگين } \\
\text { معيار) }\end{array}$ & تروه & متغير \\
\hline $\begin{array}{c}d f=\mid F=\Delta / \Lambda F f \\
P=\cdot / r r \\
\eta^{2}=\cdot / / V q\end{array}$ & $\begin{array}{c}\mathrm{F}=r r / r F \Delta \\
\mathrm{df}=r \\
\mathrm{P}=\cdot / \cdot \cdot 1 \\
\eta^{2}=\cdot / F \Delta r\end{array}$ & $\begin{array}{c}F=r r / V r G \\
\mathrm{df}=r \\
\mathrm{P}=\cdot / \cdot \cdot 1 \\
\eta^{2}=\cdot \mid Q r \Lambda\end{array}$ & 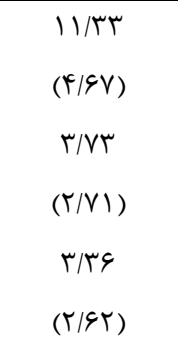 & 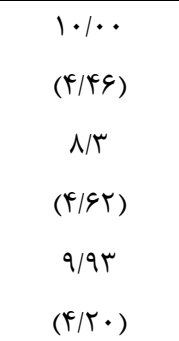 & پِيش آزمون & 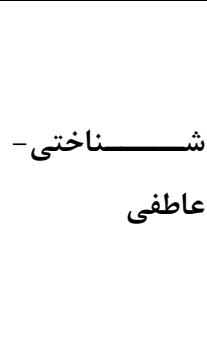 \\
\hline $\begin{array}{c}\mathrm{df}=|\mathrm{F}=r r / \kappa| q \\
\mathrm{P}=\cdot / \cdot \cdot 1 \\
\eta^{2}=\cdot / 4 \Delta \Delta\end{array}$ & $\begin{array}{c}F=r \varepsilon / r \cdot q \\
d f=r \\
P=\cdot / \cdot \cdot 1 \\
\eta^{2}=\cdot / r \wedge r\end{array}$ & $\begin{array}{c}\mathrm{df}=r \mathrm{~F}=r r / r r \Lambda \\
\mathrm{P}=\cdot / \cdot \cdot 1 \\
\eta^{2}=\cdot / r \Delta \Delta\end{array}$ & 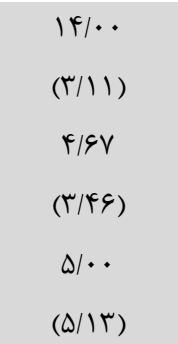 & $\begin{array}{l}\text { Ir/AV } \\
(F / V \cdot) \\
I r / T V \\
(\Delta / \cdot 9) \\
10 / 1 T \\
(T / \Delta q)\end{array}$ & "ِيش ״ِيش آزمون & 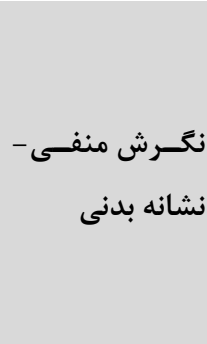 \\
\hline $\begin{array}{c}\mathrm{df}=|\mathrm{F}=| \Delta / \Delta q r \\
\mathrm{P}=\cdot / \cdot \cdot 1 \\
\eta^{2}=\cdot / r \Delta \Lambda\end{array}$ & $\begin{array}{c}\mathrm{F}=r \cdot / \Lambda q . \\
\mathrm{df}=r \\
\mathrm{P}=\cdot / \cdot \cdot 1 \\
\eta^{2}=\cdot / \Delta q r\end{array}$ & $\begin{array}{c}\mathrm{df}=r \mathrm{~F}=r \Delta / \Lambda \mid V \\
\mathrm{P}=\cdot / \cdot \cdot 1 \\
\eta^{2}=\cdot|q r|\end{array}$ & $\begin{array}{l}r \Delta / r T \\
(V / T \cdot) \\
N / F \cdot \\
(\Delta / 99) \\
N / T \cdot \\
(V / q))\end{array}$ & $\begin{array}{l}r Y / A V \\
(N / F Y) \\
r / / G . \\
(N / Y Y) \\
r \Delta / \cdot V \\
(G / \Lambda T)\end{array}$ & "ِيش & (نمرهردى كل) \\
\hline
\end{tabular}

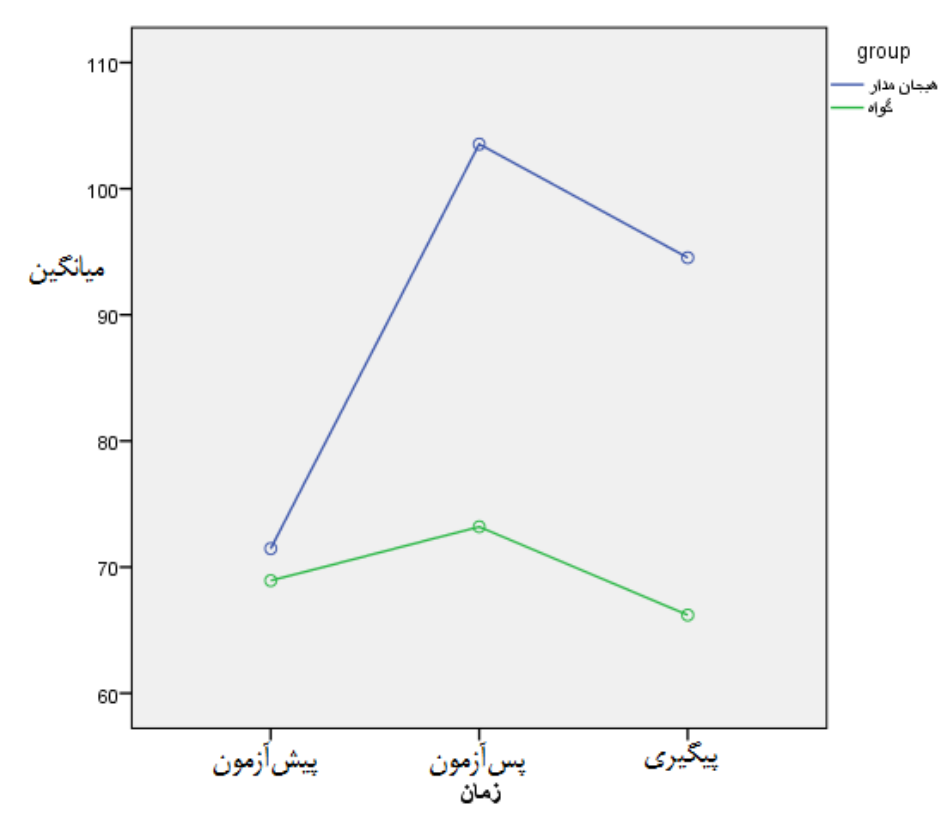

نمودار r: مقايسه ميانگين شفقتخود در سه مرحله اندازهخيرى براى گروههاى موردمطالعه 
جدول f: شاخصهاى توصيفى و نتايج حاصل از تحليل واريانس آميخته شفقت خود

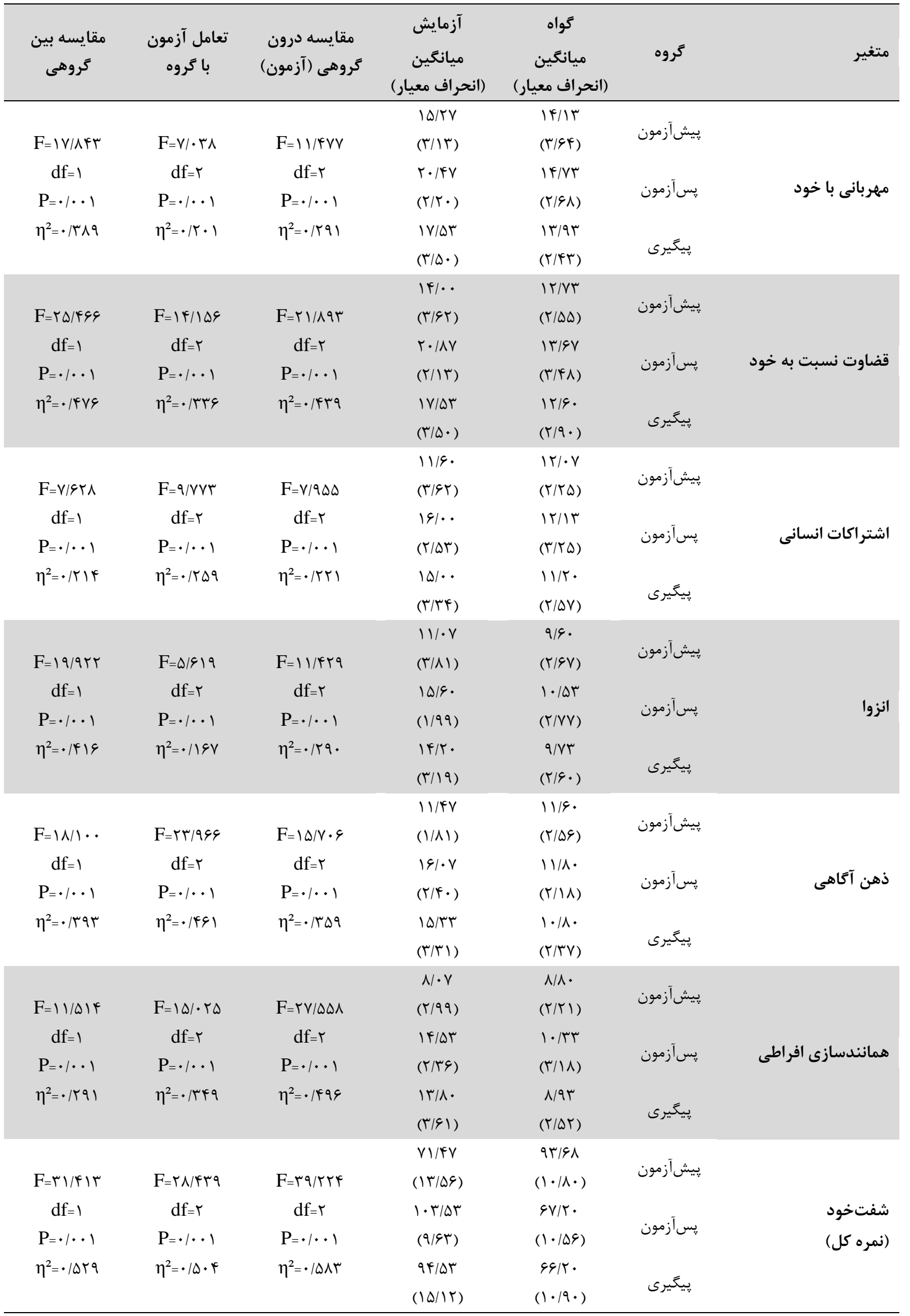


موارد اثربخشى مداخلههاى متمركز بر هيجان را تاييد يزوهش حاضر با هدف تعيين اثربخشى درمان متمركز بر در تبيين اثربخشى درمان متمركز بر هيجان در كاهش افسردگى زنان مبتلا به سرطان يستان مىتوان كَفت ابراز

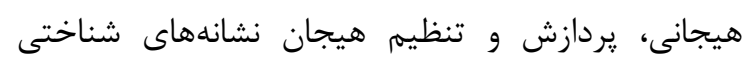

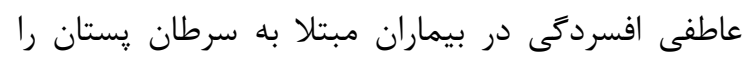

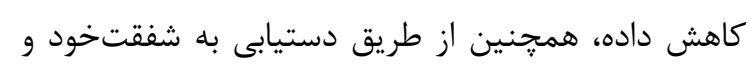

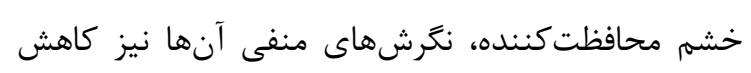

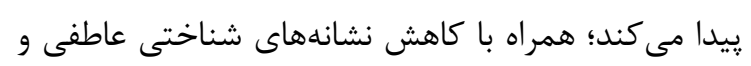

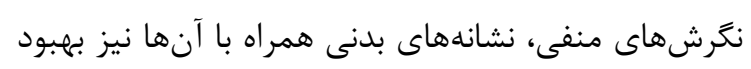

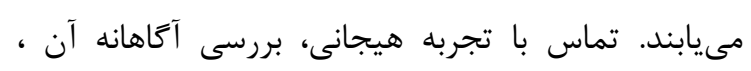

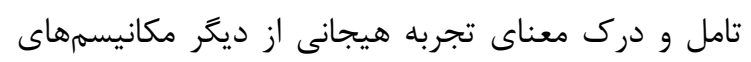

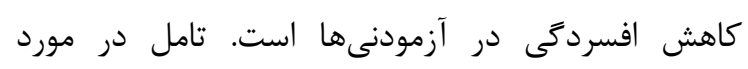

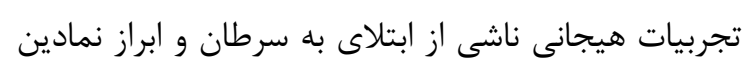

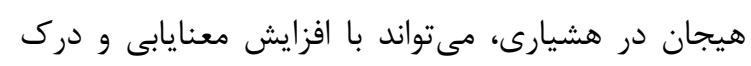

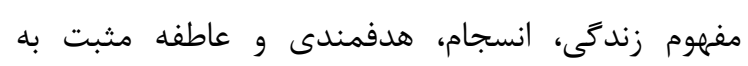

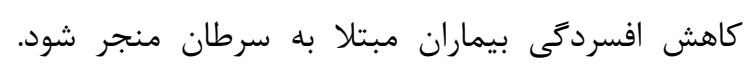

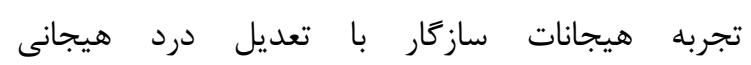
شركت كنندًان احتمال ايجاد ياسخهاى هيجانى سازگًارانه

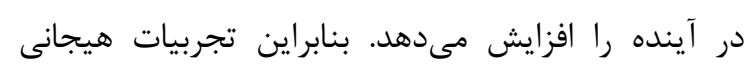

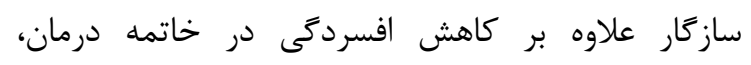

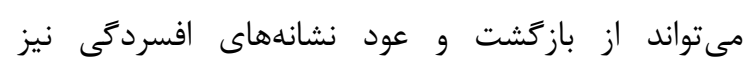

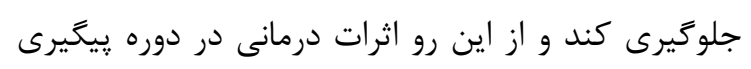
هم ثبات نشان دهند. همجنين تغيير طرحهاى هيجانى

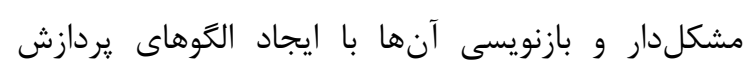

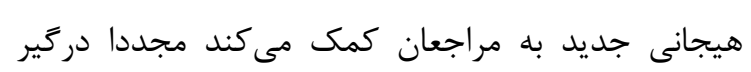
هيجانات ناسازگار دردناك اوليه و اجتناب از اين تجربيات نشوند و بهنظر مىرسد اين امر تبيينكننده ثبات نتايج درمان يَس از خاتمه جلسات باشد.

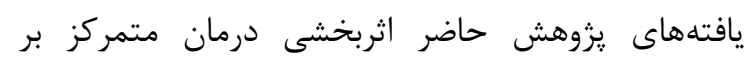

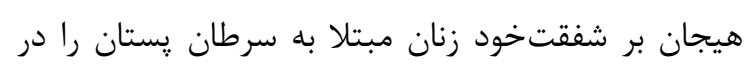

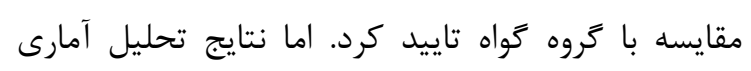

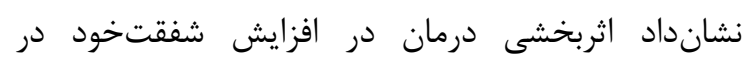
ريخيرى سهماهه حفظ نشدهاست. همسو با يافتههاى

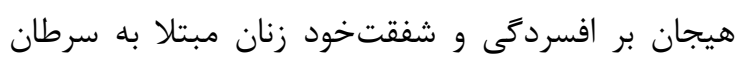

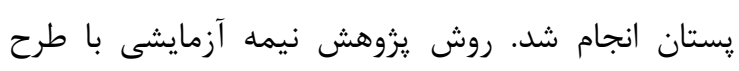

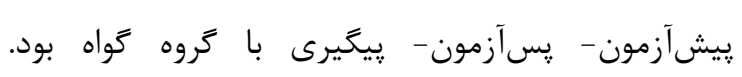

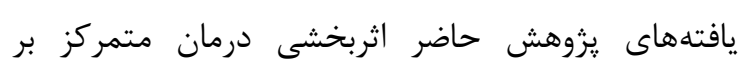

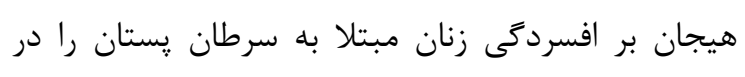

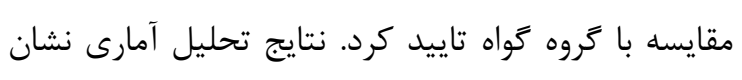
داد اثربخشى درمان در كاهش افسردىى در بيخيرى سه ماهه حفظ شدهاست.

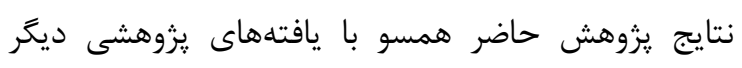

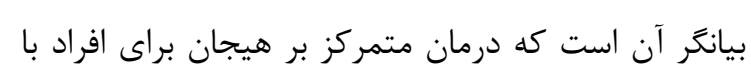

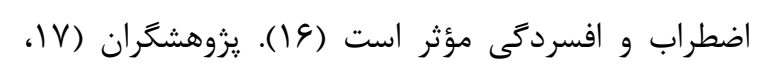

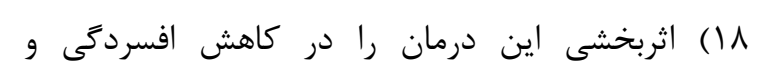
اضطراب زنان مبتلا به سرطان يستان تاييد كردهاند. همسو

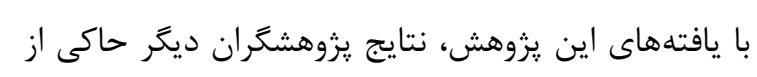

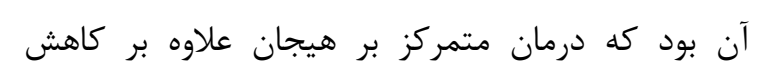

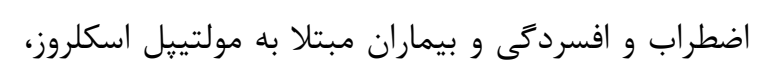
در بهبود وضعيت جسمانى بيماران نيز اثركذار است (19).

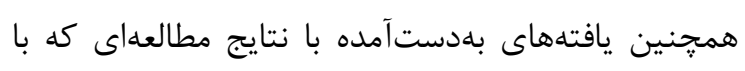

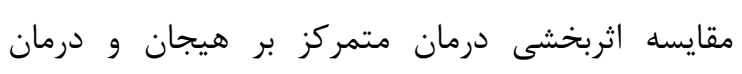

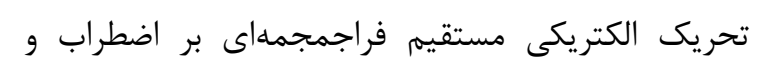
افسردگى بيمارى عروق كرونر قلبى دريافتند مداخله متمركز بر هيجان تأثير بيشترى در كاهش اضطراب و ورونر قلبى دريافنئ مداخله

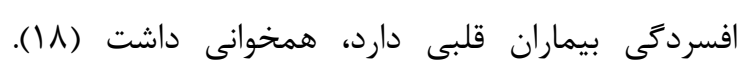

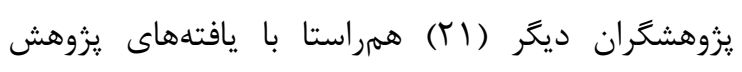

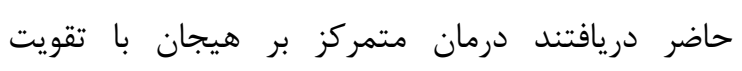

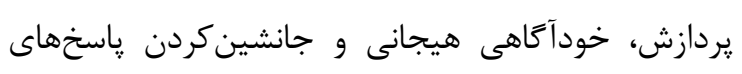

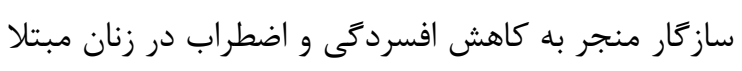
به اختلال ريرخورى مىشود. خسروى اصل و همكاران (I I IV)

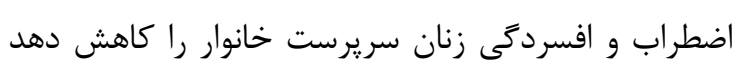

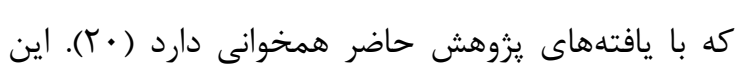


سرطانى كه با رغبت و اشتياق، فرآيند درمان را يِيخيرى مى كنند ديده مىشود. با استناد به تعريف نظرى شفقت خود، شفقت خود نوعى دودى توانايى سازگارى با شرايط كنونى است و به اين معناست كه هنكام وقوع رخداد ناراحت كننده، افراد براى كنار آمدن با اين شرايط، توانيى شفقتخود را در خود يرورش مىدهند. بنابراين شفقت خود در زمان تجربه درد و شكست بهتر نمايان مىشود (צץ) بنابراين در فاصله

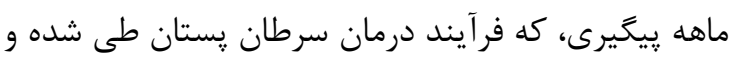

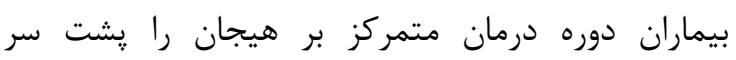
كذاشتهاند، نياز كمترى به تمرينهاى شفقت خود دارن دارند

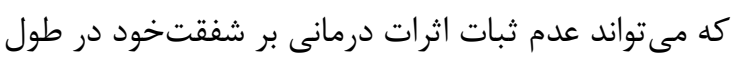

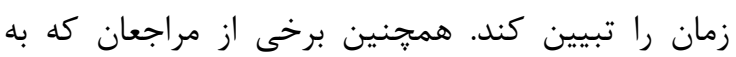
شدت طردكننده خويش هستند، ظرفيت شفقتخود پايينى دارند؛ در جنين مواردى ايجاد شفقتخود و و ابراز آن ممكن است فرايندى يِيجيدهاى باشد كه نيازمند آن است

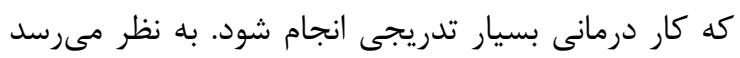
محدوديت تعداد جلسات درمانى براى اين دسته از داز

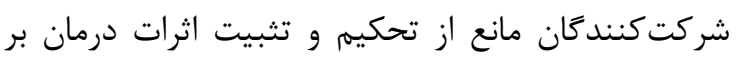
شفقتخود شده باشد. جامعه آمارى يزوهش محدود به زيه زنان مبتلا به سرطان يستان در شهر تهران بود كه به روش هدفمند انتخاب

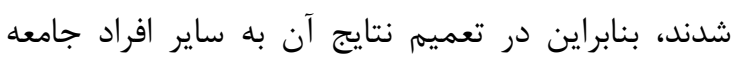

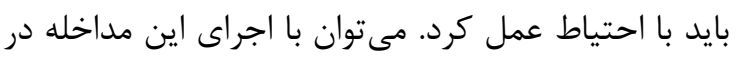
ساير گروههاى مبتلا به سرطان، ميزان تعميميذيرى نتايج درمانى را افزايش داد، همجنين بيشنهاد مىشود براى افزايش اعتبار بيرونى نتايج، از روشهاى نمونهگيرى

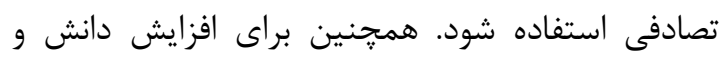

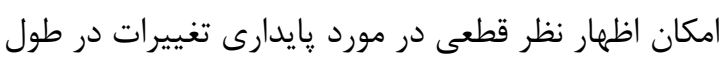

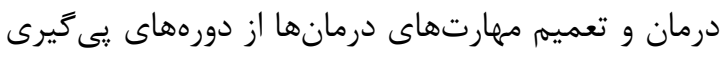

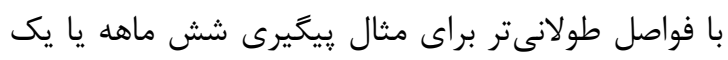
ساله) و دورههاى ييخيرى جند نقش حفاظتى شفتخود در سلامت روان، بيشنهاد مىشود تعداد جلسات مداخلات متمركز بر هيجان براى
يزوهش حاضر، نتايج يزوهش (شهر و همكاران، IT (T)

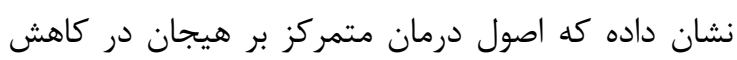
انتقاد از خود و بهبود شفقت خود موثر است (צ' (؟).

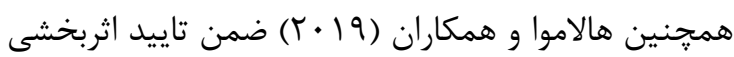

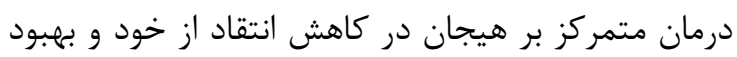
شفقتخود دريافتند اين درمان علاوه بر اثرات روانشناختى، اثرات فيزيولوزيكى ماند كاهش ضربان قلب

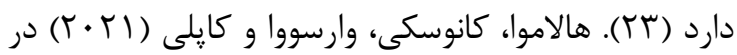

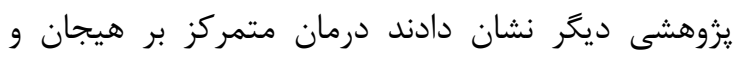

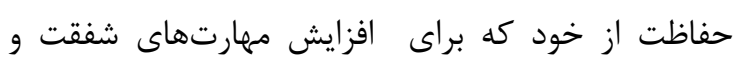
خشم محافظتى با هدف كاهش انتقاد از خود ايجاد شده

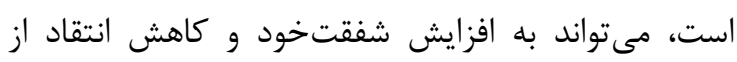

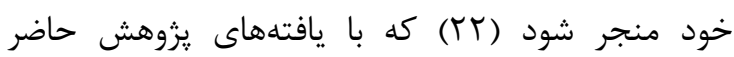

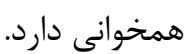
اثربخشى درمان متمركز بر هيجان در بهبود شفقت خود زنان مبتلا به سرطان يستان را مىتوان به اين صورت تبيين كرد: درمان متمركز بر هيجان از طريق كاهش اجتناب از هيجانات دردناك به افزايش شفقت خود و

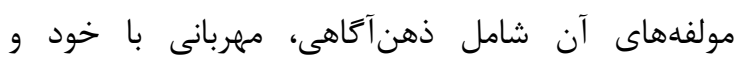
اشتراكات انسانى منجر مىشود. با بررسى دلايل بيماران

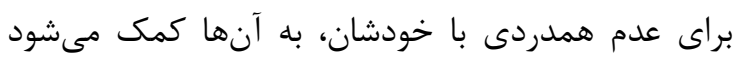
احساس شفقت را مورد يذيرش قرار دهند. درمان متمركز بر هيجان با استفاه از كفتخوهاى تصور شده، موقعيتى براى مشاهده درد فراهم كرده و موجب دستيابى به شفقتخود در مراجعان مىشود. كاربرد تكنيك كفتتوهاى تصور شده به مراجعان مى آموزد فرايندهاى درونى مربوط مران مردي

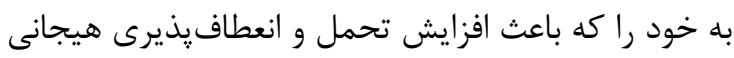

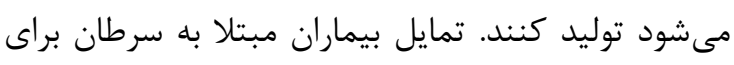
يذيرش درد به جاى اجتناب و كريز از آن مىتواند نئن اثربخشى درمان متمركز بر هيجان بر افزايش شفقت خود اجد

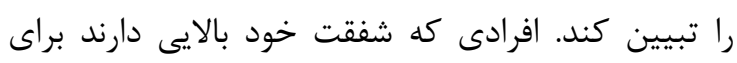
سبك كردن رنجش جهت شفايابى، به جاى اجتناب و كريز از درد، آن را مىيذيرند و اين خاصيت در بيماران 


$$
\text { كاهش افسردگى به بهبود كيفيت زندگى در زنان مبتلا به }
$$$$
\text { تشكر و قدردانى }
$$

از زحمات سركار خانم دكتر ناهيد نفيسى، جناب آقاى

دكتر همايون ذوالفقارىنيا و مساعدت كليه آزمودنىهاى

تحقيق حاضر كه با صبورى، يزوهشگران را در طى فرآيند

تحقيق يارى نمودهاند صميمانه تقدير مىشود.

$$
\begin{aligned}
& \text { تعارض منافع } \\
& \text { نويسند } \\
& \text { يثروش حاضر وجود ندارد. }
\end{aligned}
$$

$$
\begin{aligned}
& \text { بررسى ثبات اثربخشى اين درمان بر شفقت خود در } \\
& \text { بيماران مبتلا به سرطان افزايش يابد. } \\
& \text { نتبجه } \\
& \text { نتايج بهدست آمده از يزوهش حاضر نشان داد درمان } \\
& \text { متمركز بر هيجان در بيماران مبتلا به سرطان يستان به } \\
& \text { ميزان قابل توجهى افسردگى را كاهش داده و موجب } \\
& \text { افزايش شفقت خود مىشود. درمان متمركز بر هيجان از } \\
& \text { طريق افزايش شفقت خود، موجب كاهش انتقاد از خود و } \\
& \text { عواطف منفى مىشود، به بيماران كمك مى كند قضاوت از } \\
& \text { خود را مورد ارزيابى قرار داده و نسبت به آشفتگى هايى كه } \\
& \text { بر كيفيت زندگى آنها اثر مى گذارد به درك و فهمه } \\
& \text { مشفقانهاى برسند كه به آنها در يذيرش هشيارانه } \\
& \text { احساسات و افكارشان يارى برساند. اين فرايندها علاوه بر }
\end{aligned}
$$

\section{References}

1. Jelveh $\mathrm{M}$, Vafaee-najar A, Rahbari S, Daghighbin E. Evaluation of Knowledge, Attitude, and Practice of Women on Breast Cancer and its Screening: A Step towards Health Reform. Navid No. 2021; 23(76): 5262.

2. Nakamura ZM, Deal AM, Nyrop KA, Chen YT, Quillen LJ, Brenizer T, Muss HB. Serial assessment of depression and anxiety by patients and providers in women receiving chemotherapy for early breast cancer. The Oncologist. 2021; 26(2): 147-56.

3. Zainal NZ, Ng CG, Wong A, Andrew B, Mohd Taib NA, Low SY. Prevalence of depression, trait anxiety, and social support during the diagnostic phases of breast cancer Journal of Taibah University Medical Sciences. 2021; 16(4): 497-503.

4. Adjei Boakye E, Osazuwa-Peters N, Mohammed KA, Challapalli S, Buchanan P, Burroughs TE, Varvares MA. Prevalence and factors associated with diagnosed depression among hospitalized cancer patients with

metastatic disease. Social Psychiatry and Psychiatric Epidemiology. 2020; 55(1): 15-23.

5. Nikbakhsh N, Moudi S, Mohammadian Amiri F, Niazifar M, Bijani A. Depression, Anxiety, and Quality of Life in Breast Cancer Patients with Depression Receiving Citalopram and Supportive Group Psychotherapy: A Sixmonth Longitudinal Study. Journal of Mazandaran University of Medical Sciences. 2019; 29 (173) :64-74.

6 Kyei K.A, Oswald J.W, Njoku A.U, Kyei J.B, Vanderpuye V, Tschida P. Anxiety and Depression among Breast Cancer Patients Undergoing Treatment in Ghana. African Journal of Biomedical Research. 2020; 23(2): 227-32.

7. Neff K. D. The development and validation of a scale to measure self-compassion. Self and Identity. 2003; 2(3): 223-50.

8. Zhu L, Wang J, Liu S, Xie H, Hu Y, Yao J et al. Self-Compassion and Symptoms of Depression and Anxiety in Chinese Cancer Patients: the Mediating Role of Illness 
Perceptions. Mindfulness. 2020 ;11(10): 238696.

9. Abdollahi A, Taheri A, Allen KA. Selfcompassion moderates the perceived stress and self-care behaviors link in women with breast cancer. Psycho-Oncology. 2020; 29(5): 927-33.

10. Przezdziecki A, Sherman KA, Baillie A, Taylor A, Foley E, Stalgis-Bilinski K. My changed body: breast cancer, body image, distress and self-compassion. PsychoOncology. 2013 ;22(8) :1872-9.

11. Van der Donk LJ, Fleer J, Tovote A, Ranchor AV, Smink A, Mul VEM et al. The role of mindfulness and self-compassion in depressive symptoms and affect: A Comparison between Cancer Patients and Healthy Controls. Mindfulness. 2020; 11(4): 883-94.

12. Greenberg LS. Emotion-focused therapy. Theories of psychotherapy series. Washington, DC: American Psychological Association; 2011.

13. Geller SM, Greenberg LS. Therapeutic presence: A mindful approach to effective therapy. American Psychological Association; 2012.

14. Herrmann IR, Greenberg LS, Auszra L. Emotion categories and patterns of change in experiential therapy for depression. Psychotherapy Research. 2016; 26(2): 178-95.

15. Greenberg LS. Emotion-focused therapy of depression. Person-Centered \& Experiential Psychotherapies. 2017; 16(2), 106-17.

16. Hissa J, Connolly A, Timulak L, \& Hession N. Emotion-focused perspective on breast cancer patients' experiences of comorbid anxiety and depression: a qualitative case analysis of three clients' in-session presentations. Person-Centered \& Experiential Psychotherapies. 2020; 19(2): 134-53.

17. Connolly-Zubot A, Timulak L, Hession N, \& Coleman N. Emotion-focused therapy for anxiety and depression in women with breast cancer. Journal of Contemporary Psychotherapy .2020; 50(2): 113-22.

18. Gili S, Sadeghi zavareh V, Haghayegh S, Alizadeh ghavidel A, rezayi jamalloi $\mathrm{H}$. The Comparison of Effectiveness of EmotionFocused Therapy and Transcranial Direct Current Stimulation on Anxiety and Depression of Patients with Coronary Artery Disease. Quarterly Journal of Health Psychology. 2021; 9 (36): 45-62.

19. Sanagavi Moharrar G, Shirazi M, Mohammadi R, Maghsoodloo F. Effectiveness of Emotional Therapy on Reducing Anxiety and Depression in Patients with Multiple
Sclerosis. Medical Journal of Mashhad University of Medical Sciences. 2019; 61(1): 190-200.

20. Khosravi Asl M, Nasirian M, Bakhshayesh A. The Impact of Emotion-focused Therapy on Anxiety and Depression among FemaleHeaded Households in Imam Khomeini Relief Committee. Journal of Community Health Research. 2018; 7(3): 173 -82.

21. Asmaribardezard Y, Mohamadaminzade D, Hosiesabet F. Effectiveness of Emotionfocused Therapy on Depression and Anxiety in Women with Binge Eating Disorder referring to Sina Hospital in 1396. Navid No, 2018; 21(65): 11-22.

22. Halamová, J, Kanovský M, Varšová K, Kupeli N. Randomised controlled trial of the new short-term online emotion focused training for self-compassion and selfprotection in a nonclinical sample. Current Psychology. 2021; 40(1):333 -43.

23. Halamová J, Koróniová J, Kanovský M, Túniyová M. K, \& Kupeli N. Psychological and physiological effects of emotion focused training for self-compassion and selfprotection. Research in Psychotherapy: Psychopathology, Process and Outcome. 2019; 22(2): 265- 80.

24. Timulak L. Transforming emotional pain in psychotherapy: An emotion-focused approach. London: Routledge; 2015.

25. Timulak L, Pascual-Leone A. New Developments for Case Conceptualization in Emotion-Focused Therapy Clinical Psychology and Psychotherapy. 2015; 22(6): 619-36.

26. Shahar B, Carlin ER, Engle DE, Hegde J, Szepsenwol O, Arkowitz H. A pilot investigation of emotion-focused two-chair dialogue intervention for self-criticism. Clinical Psychology \& Psychotherapy. 2012; 19(6): 496-507.

27. Shahar B, Bar-Kalifa E, Alon E. Emotionfocused therapy for social anxiety disorder: Results from a multiple-baseline study. Journal of Consulting and Clinical Psychology .2017; 85(3): 238-49.

28. Noel-Hoeksema S, Fredrickson B, loftus G. and Wagenaar W. Atkinson \& Hilgard's introduction to psychology. 16th ed. Hampshire: Cengage Learning EMEA; 2014.

29. Hashemian S, Shams G, Ashayeri H, Modarres Gharavi M. Investigating the impact of emotional display rules on the positive/negative affect. Journal of Fundamentals of Mental Health, 2016; 18(6): 338-42. doi: 10.22038/jfmh.2016.7807. 
30. Delavar A. Theoretical and practical foundations of research in humanities and social sciences. Tehran: Roshd Publication; 2015.

31. Greenberg LS. Emotion-focused therapy: Coaching clients to work through feelings. 2nd ed. Washington DC: American Psychological Association; 2015.

32. Elliott R, Watson JC, Goldman RN, \& Greenberg LS. Learning emotion-focused therapy: The process-experiential approach to change. Washington DC: American Psychological Association; 2004.

33. Beck AT, Steer RA, Brown GK. Manual for the Beck Depression Inventory-II. San
Antonio, TX: Psychological Corporation; 1996.

34. rajabi G., karju kasmai S. Psychometric properties of a Persian language version of the beck depression inventory second edition. Quarterly of Educational Measurement. 2012; 3(10): 139-58.

35. Khosravi S, Sadeghi M, Yabande M. Psychometric Properties of Self-Compassion Scale (SCS). Journal of Psychological Models and Methods. 2013; 3(13): 47-58.

36. Foroughi A A, Khanjani S, Rafiee S, Taheri A A. Self-compassion: conceptualization, research, and interventions (Brief review). Shenakht Journal of Psychology and Psychiatry. 2020; 6 (6) :77-87. 